\title{
TONER USED IN THE DEVELOPMENT OF FOAMED CONCRETE FOR STRUCTURAL USE
}

\author{
P. A. Shawnim ${ }^{1}$ and F. Mohammad ${ }^{1}$ \\ 4BU, UK. Phone: (+44 7438199426) \\ Date received: 17/02/2018, Date accepted: 19/04/2018 \\ Corresponding author"s email: paybar.shawnim2014@my.ntu.ac.uk,
}

${ }^{1}$ School of Architecture, Design and the Built Environment, Nottingham Trent University, Burton Street, Nottingham, NG1

\begin{abstract}
This paper investigates the effect of toner as a new material on enhancing compressive strength and permeability of foamed concrete (FC). The aim is to develop the FC through testing the reaction of toner with the cement of the FC, to produce a hydrophobic lightweight FC to use for structural elements. Foamed concrete is generally made of ordinary Portland cement (OPC), sand, foaming agent, and water with a well spread pore structure. The experiment was carried out on $100 \mathrm{~mm}$ cubes. Results for toner inclusion of all the mixes, when added in the right quantities, showed high improvement for water penetration and compressive strength in comparison to the published data on FC for the use as structural material, which is a step forward in the advancement of FC to meet the aim of this research.
\end{abstract}

Copyright (C) 2018 UNIMAS Publisher. This is an open access article distributed under the Creative Commons Attribution-NonCommercial-ShareAlike 4.0 International License which permits unrestricted use, distribution, and reproduction in any medium, provided the original work is properly cited.

Keywords: Compressive strength, Foamed concrete, Permeability, Toner.

\subsection{INTRODUCTION}

Foamed concrete (FC) is a lightweight material made up of Ordinary Portland cement paste (OPC and a filler, usually sand) and water with a well spread air voids or pore structure created by the introduction of air by mechanical means of foaming. The foam can be originated from an agent made of natural surfactants or synthetic materials, and can be added to the concrete mix either as pre foamed (where the foam is prepared in advance by the foaming machine and added later) or as mixed foaming (the foam is added to the mix at the same time as it is prepared) [1]. Foamed concrete is a lightweight material with low densities of between (400 - 1800) kg/m ${ }^{3}$ [2] incorporating a high volume of air, highly workable, self-flowing, selfcompacting and self-levelling with fire resisting, thermal insulating and sound proofing properties. The typical strength value for foamed concrete of densities between $(800-1600) \mathrm{kg} / \mathrm{m}^{3}$ is between $(1-10)$ $\mathrm{N} / \mathrm{mm}^{2}$, see Table 1 [3]. Foamed concrete produced in this range can only be used for general purposes, such as gap fillings. But at a minimum strength of $25 \mathrm{~N} / \mathrm{mm}^{2}$, foamed concrete has the potential to be used as a structural material [4], [5].

Table 1 Summary of properties of hardened foamed concrete [3]

\begin{tabular}{lc}
\hline Density $(\mathrm{kg} / \mathrm{m} 3)$ & Compressive strength $(\mathrm{N} / \mathrm{mm} 2)$ \\
\hline 400 & $0.5-1.0$ \\
600 & $1.0-1.5$ \\
800 & $1.5-2.0$ \\
1000 & $2.5-3.0$ \\
1200 & $4.5-5.5$ \\
1400 & $6.0-8.0$ \\
\hline
\end{tabular}

While, Table 2 shows the maximum compressive strength of $28.5 \mathrm{~N} / \mathrm{mm}^{2}$ reached [6]. 


\section{Journal of Civil Engineering, Science and Technology}

Volume 9, Issue 1, April 2018

Table 2 Compressive strength of foamed concrete at different densities [6]

\begin{tabular}{lcc}
\hline \multirow{2}{*}{ Fine aggregate type } & Plastic density $\mathrm{kg} / \mathrm{m}^{3}$ & 28-day compressive strength $\left(\mathrm{N} / \mathrm{mm}^{2}\right)$ \\
\hline \multirow{3}{*}{ Sand } & 1400 & 13.5 \\
& 1600 & 19.5 \\
& 1800 & 28.5 \\
\hline
\end{tabular}

The protein based foam agents result in a stronger and a more closed-cell bubble structure, which permits the inclusion of greater amounts of air and provides a more stable air void matrix, while the synthetic foam agents yield greater expansion and thus lower density [7]. The content of the foaming agent has a considerable effect on the properties of fresh and hardened concrete. Therefore, the mechanical and physical properties of FC can vary depending on the type of foaming agent and dosage used in the mix [8]. It has been reported that the excessive foam volume results in a drop in flow, decrease in density, and decrease in compressive and tensile strengths [7]. Standard protein based foaming agents are formed by the process of protein hydrolysis using animal proteins from horn, blood, bones of cows or other remainders of animal carcasses. While Synthetic foaming agents are amphiprotic substance that are strongly hydrophilic and easily dissolve in water yielding air bubbles. However, when introducing synthetic agents into concrete, which is a complex chemical environment, the compatibility of surfactant and cement particles is critical to effectively entrain the desired air content and concrete microstructure [8]. The foam should be steady and stable to be able to resist the mortar pressure until the cement initially sets. This helps to build up a strong skeleton of concrete all over the voids filled with air [7].

This paper examines strength and permeability of toner (newly introduced material through this research) in the development of FC to produce a hydrophobic lightweight foamed concrete with enhanced properties to be used as a structural material. Foamed concrete is highly permeable, recently its potential as a semistructural material came to light. It is generally used in building construction as low strength concrete for foundations, thermal and sound insulations, and in areas where resistance to frost is a requirement [9]. Classification of aerated concrete (AC) based on the method of pore-formation can be summarized as airentraining method (gas concrete), foaming method (foamed concrete, FC) and combined method [10]. Autoclave is a form of curing, using heat treatment for early gain of concrete strength. The second type of aerated concrete is FC, for which no chemical reactions are involved. The cement content of the foamed concrete for all research studies was kept constant at $(500-600) \mathrm{kg} / \mathrm{m}^{3}$, which is comparable to other studies [11]-[13]. Addition of toner at $1 \%$ or $5 \%$ by weight of the cement, had no effect on water demands for the mixes involved.

\subsection{TONER}

This is a newly introduced material particular to this research, therefore, there is no published data available at all for its usage in this field of FC. This material comes in the form of a powder, which is going to be used as an additive to the experimental mixes, at $1 \%$ and $5 \%$ of the binding cementitious material (cement). This material is chosen for this research because it is widely available as a waste material for recycling and to help cleaning the environment by reducing buried waste and $\mathrm{CO} 2$ emission around the world. Table (3) shows chemical composition for toner. Also, toner includes the following additives for flow and lubrication purposes: Fumed silica and metal stearates. 


\section{Journal of Civil Engineering, Science and Technology}

Volume 9, Issue 1, April 2018

Table 3 Chemical composition of toner [14]

\begin{tabular}{lc}
\hline Toner Type & Composition \\
\hline $\begin{array}{l}\text { Plastic (Styrene acrylate copolymer, polyester } \\
\text { resin) }\end{array}$ & $65-85 \%$ or $55-65 \%$. \\
Iron oxide & $6-12 \%$ or $30-40 \%$. \\
Wax, ground sand & $1-5 \%$ \\
Amorphous silica & $1-3 \%$ \\
Carbon black & $1-10 \%$. \\
\hline
\end{tabular}

\subsection{EXPERIMENTAL WORK}

The experiments were carried out in the laboratory in accordance to the relevant British Standards (BS) for each part of the process. Sets of $100 \times 100 \times 100 \mathrm{~mm}$ plastic cube moulds were used to cast the normal weight concrete samples, whereas, disposable polystyrene cube moulds were used to cast all concrete samples containing foam to avoid the use of release agent and enabling the sealed curing process of the desired period of 28 days, figures ( 1 and 2). Eleven batches of different concrete mixes, made with OPC and sand, with a w/c ratio of 0.5 . Only 5 out of the 11 batches made with the inclusion of toner at $1 \%$ and $5 \%$. The foam was added at different percentages to the mixes to produce the desired densities. The foaming agent used in this project was a protein based foaming agent, dry pre-foaming method was used to generate the foam. All specimens cured for 28 days.

For a target plastic density $\left(\mathrm{D}, \mathrm{kg} / \mathrm{m}^{3}\right)$ and water/cement ratio (w/c), the binder content $\left(\mathrm{Cement}, \mathrm{kg} / \mathrm{m}^{3}\right)$, the total mix water $\left(\mathrm{W}, \mathrm{kg} / \mathrm{m}^{3}\right)$ and fine aggregate content $\left(\right.$ Sand, $\left.\mathrm{kg} / \mathrm{m}^{3}\right)$ are calculated from the following mix design equation:

$$
\mathrm{D}=\mathrm{C}+\mathrm{W}+\mathrm{F}
$$

Where $\quad \begin{array}{ll}\mathrm{D}=\text { target plastic density, } \mathrm{kg} / \mathrm{m}^{3} & \mathrm{C}=\text { binder (cement content) } \mathrm{kg} / \mathrm{m}^{3} \\ \mathrm{~W}=\text { water content, } \mathrm{kg} / \mathrm{m}^{3} & \mathrm{~F}=\text { filler (fine aggregate, sand) } \mathrm{kg} / \mathrm{m}^{3}\end{array}$

\subsection{COMPRESSIVE STRENGTH AT 28 DAYS}

The test was carried out with a digital log keeping and digitally controlled automatic loading machine in accordance with BS EN 12390-3:2009 [15]. The oven dried cubes were placed centrally under the loading plates and positioned to have even surfaces in contact with the loading plates, figures (3A and 3B). Results quoted in each case are the average of six specimens.

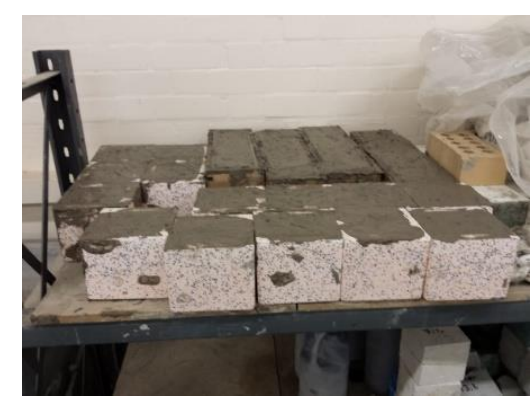

Figure 1 Disposable polystyrene cube moulds of the size $(100 \times 100 \times 100) \mathrm{mm}$.

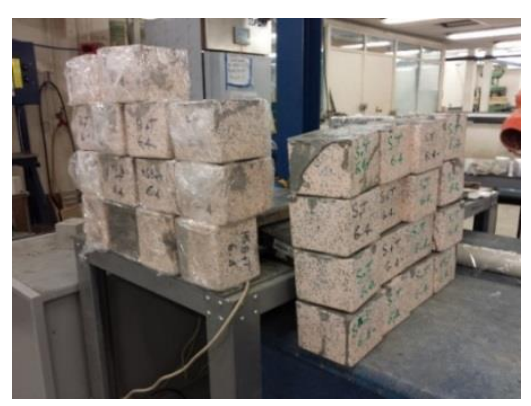

Figure 2 Sealed cubes in cling film as a method of curing. 


\section{Journal of Civil Engineering, Science and Technology}

Volume 9, Issue 1, April 2018

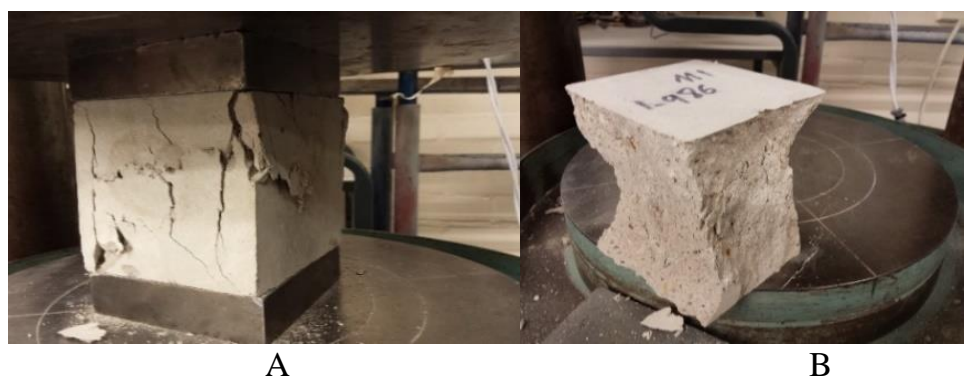

Figure 3, A; Cube between plates under compression, B; Cube after crushing.

\subsection{PERMEABILITY AT 28 DAYS IS MEASURED THROUGH CAPILLARY WATER ABSORPTION AND TOTAL WATER ABSORPTION}

\subsubsection{CAPILLARY WATER ABSORPTION}

Capillary water absorption test was carried out under 5 bar pressure in accordance with BS EN 123908:2009 [16]. Three oven dried specimens put under the 5 bar permeability test apparatus for 72 hours, after which they are taken out and split open to mark and measure water penetration from bottom up, results expressed in millimetres (mm), Figures 4 and 5.

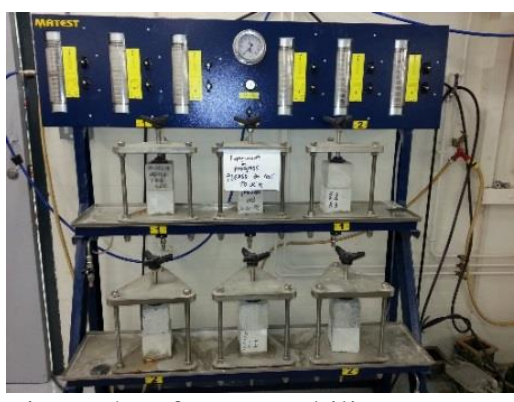

Figure 4 Left; Permeability apparatus

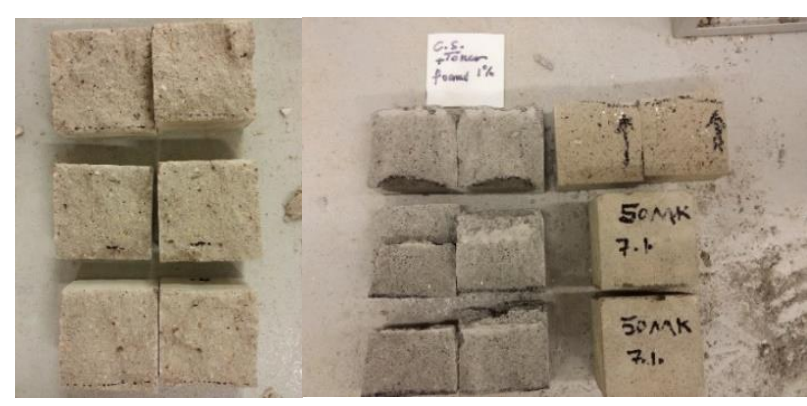

Figure 5 Specimens split open and marked

\subsubsection{TOTAL WATER ABSORPTION}

Total water absorption test was carried out in accordance with BS 1881-122:2011 [17]. Three oven dried were totally immersed in water for at least 72 hours, after which they were taken out to measure weight of absorbed water. The absorbed water was determined from the difference in weight between fully water saturated and dried state of a specimens. Results expressed in $\left(\mathrm{kg} / \mathrm{m}^{3}\right)$ or in $(\%)$ of the dried weight.

\subsection{RESULTS AND DISCUSSIONS}

\subsection{COMPRESSIVE STRENGTH}

This part will be analysed based on the emerging results for the different densities, and on the bases of the $28.5 \mathrm{~N} / \mathrm{mm}^{2}$ compressive strength set as a standard from Table 2, see Figure 6 and Table 4:

Through the highest to the lowest density of 1800 to $500 \mathrm{~kg} / \mathrm{m}^{3}, \mathrm{~S} 7$ to $\mathrm{S} 11$ showed higher compressive strength of 49.3 to $5.1 \mathrm{~N} / \mathrm{mm}^{2}$, compared to those corresponding compressive strengths of S2 to S6 made with no toner inclusion. The reaction between the constituents of the toner i.e. the iron oxide and the silica with the chemical composition of the binding material, results in a strong intercellular bond, in turn, a higher compressive strength.

- The use of toner upgrades the strength to a much higher level, taking S8 of $55.1 \mathrm{~N} / \mathrm{mm}^{2}$ as an example, the strength has increased by $93 \%$ (almost by two folds) over the $28.5 \mathrm{~N} / \mathrm{mm}^{2}$ set as a standard.

- Looking at the very low densities of the $500 \mathrm{~kg} / \mathrm{m}^{3}, \mathrm{~S} 11$ of $5.1 \mathrm{~N} / \mathrm{mm}^{2}$, again, they have shown improvement by about $40 \%$ compared to those figures published within the literature review of $(0.5$ $-2.0) \mathrm{N} / \mathrm{mm}^{2}$ for those matching densities. 


\section{Journal of Civil Engineering, Science and Technology}

Volume 9, Issue 1, April 2018

- Most of the above discussed results obtained for foamed concrete with toner inclusion of S7 to S9, closely match that of the sand mix normal concrete of $2000 \mathrm{~kg} / \mathrm{m}^{3}$, taken as a controlled concrete mix for comparison.

Table 4 Labelling for fillers of different concrete mixes and their densities

\begin{tabular}{|c|l|l|}
\hline \multirow{2}{*}{ Labeling } & \multicolumn{1}{|c|}{ Type of concrete cast } & \multicolumn{2}{|c|}{ Dry density } \\
\cline { 3 - 3 } & & \multicolumn{1}{|}{$\mathrm{Kg} / \mathrm{m}^{3)}$} \\
\hline S1 & Sand & 2000 \\
\hline S2 & Sand & 1800 \\
\hline S3 & Sand & 1600 \\
\hline S4 & Sand & 1300 \\
\hline S5 & Sand & 1000 \\
\hline S6 & Sand & 600 \\
\hline S7 & Sand and Toner & 1800 \\
\hline S8 & Sand and Toner $(5 \%)$ & 1700 \\
\hline S9 & Sand and Toner $(5 \%)$ & 1600 \\
\hline S10 & Sand and Toner $(1 \%)$ & 1100 \\
\hline S11 & Sand and Toner $(1 \%)$ & 500 \\
\hline
\end{tabular}

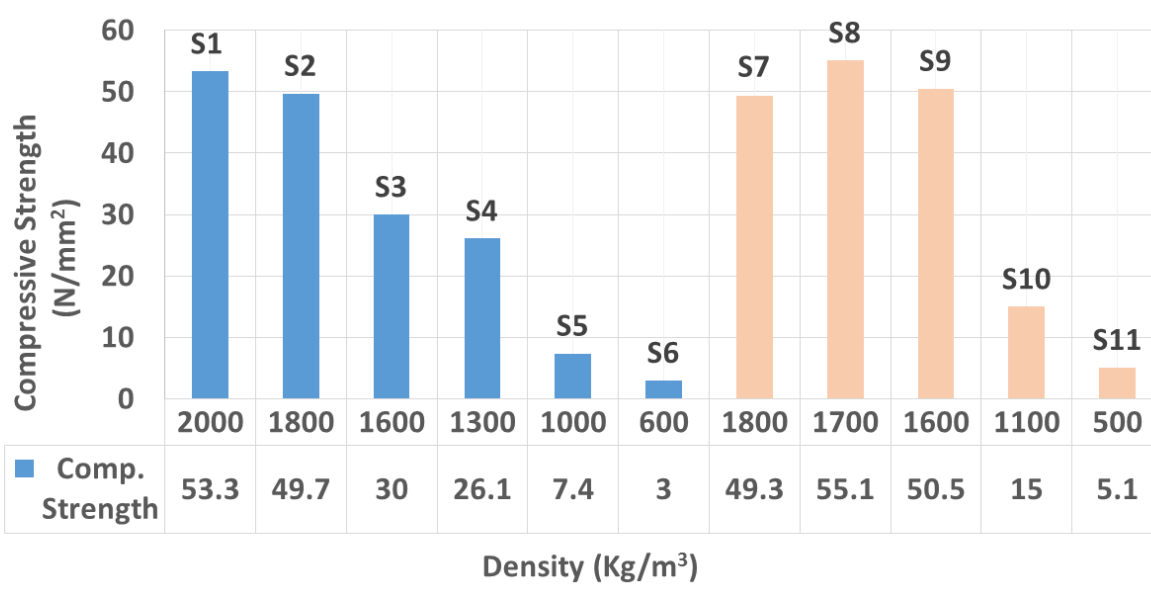

Figure 6 Compressive strength versus density for different mixes contain sand and toner

\subsection{PERMEABILITY}

\subsubsection{CAPILLARY EATER ABSORPTION UNDER 5 BAR PRESSURE}

All specimens made with toner inclusion, showed superior qualities over those made with the same corresponding mixtures but without the inclusion of toner, see S7 to S10, Figure 7 and Table 4.

S7 of $1800 \mathrm{~kg} / \mathrm{m}^{3}, 2 \mathrm{~mm}, \mathrm{~S} 8$ of $1700 \mathrm{~kg} / \mathrm{m}^{3}, 1 \mathrm{~mm}, \mathrm{~S} 9$ of $1600 \mathrm{~kg} / \mathrm{m}^{3}, 3 \mathrm{~mm}$, showed less water penetration of $26 \mathrm{~mm}$ for the normal concrete of $\mathrm{S} 1$ specimen made without toner inclusion of $2000 \mathrm{~kg} / \mathrm{m}^{3} \mathrm{density}$. 


\section{Journal of Civil Engineering, Science and Technology}

Volume 9, Issue 1, April 2018

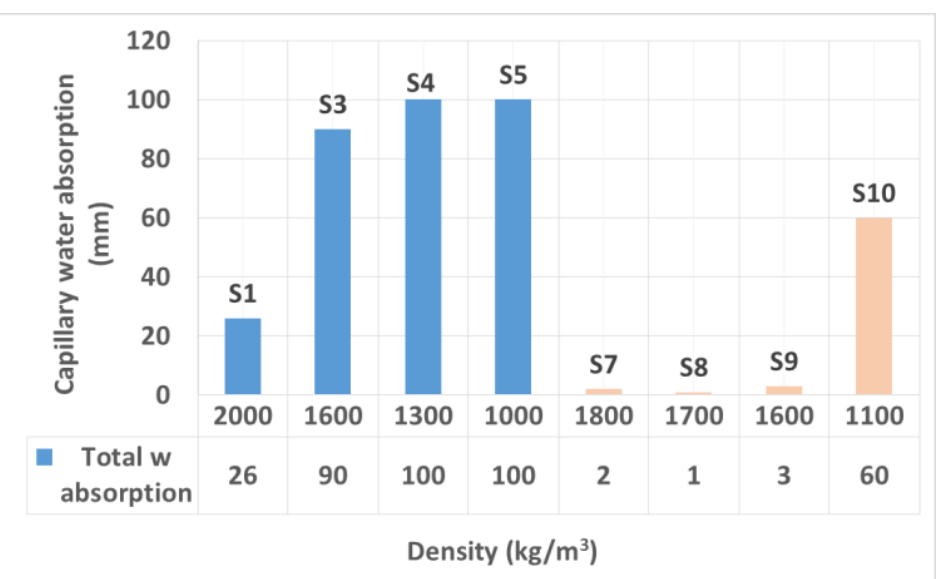

Figure 7 Capillary water absorption $(\mathrm{mm})$ versus density for different mixes with and without toner inclusion

\subsubsection{TOTAL WATER ABSORPTION}

Looking through Figures 8 and 9, all specimens with the inclusion of toner, S7 to S10 recorded permeability of the range between $\left(7 \%\right.$ to $12.5 \%$ ) or $(115.2$ to 138.5$) \mathrm{kg} / \mathrm{m}^{3}$ of their dry weight while all the rest of the specimens made without the inclusion of toner show higher permeability of the range between $(9.3 \%$ to $38.8 \%$ ) of their dry weight, or (187.7 to 388.7$) \mathrm{kg} / \mathrm{m}^{3}$ water absorption. Specimens S7 to $\mathrm{S} 10$ showed less permeability compared to $\mathrm{S} 1$ specimen which is $187.7 \mathrm{~kg}$ for normal concrete of 2000 $\mathrm{kg} / \mathrm{m}^{3}$, therefore, toner inclusion showed improvement in this respect, Figure 9 and Table 4.

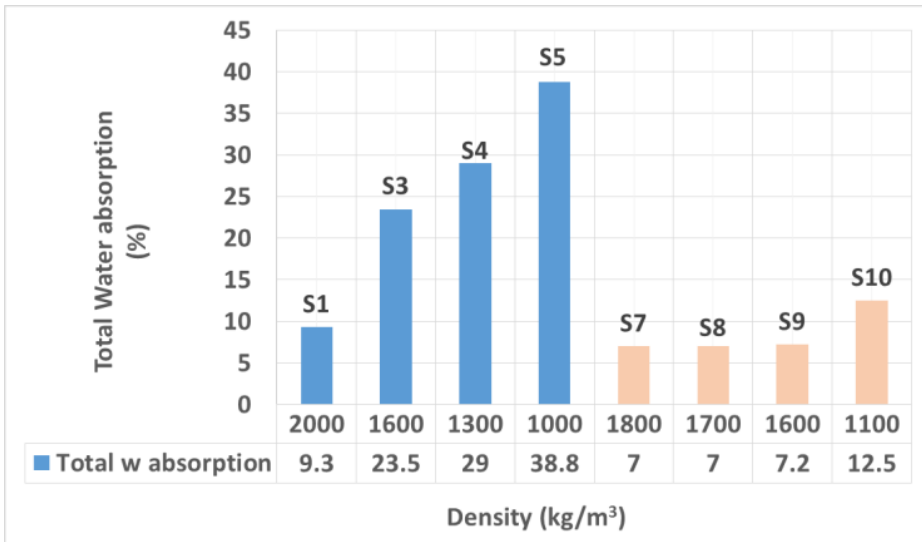

Figure 8 Total water absorption (\%) of dry weight versus density for different mixes with and without toner inclusion.

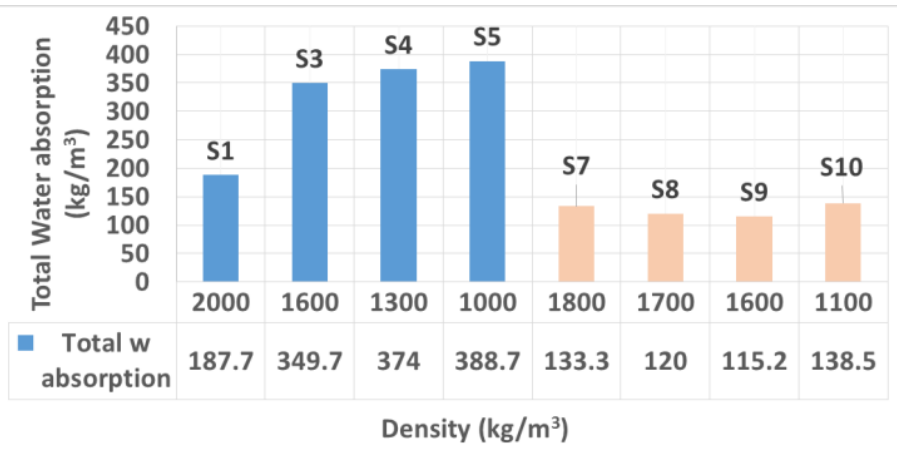

Figure 9 Total water absorption $\left(\mathrm{kg} / \mathrm{m}^{3}\right)$ of dry weight versus density for different mixes with and without toner inclusion

In both cases of the capillary water absorption and total water absorption improvements, the lubricating metal stearates from the toner forming a fine coating film around the binding particles and the voids, resulting in a stronger and closely packed hydrophobic (water repellant) cellular concrete matrix. 


\section{Journal of Civil Engineering, Science and Technology}

Volume 9, Issue 1, April 2018

\subsection{CONCLUSIONS}

The following conclusions can be drawn from the present study:

Toner at 5\% dose, proved to be an excellent viable material for inclusion in foamed concrete (FC), improving compressive strength almost by up to two folds compared to those demonstrated through figures published by BCA [2]. Permeability test through capillary water absorption is improved to reach a minimum of a few millimetre water penetrations, i.e. close to zero, which cannot easily be obtained even with normal concrete of high densities. Permeability test through total water absorption is also improved to values that only the normal concrete of high densities of $2000 \mathrm{~kg} / \mathrm{m}^{3}$ and beyond can reach, i.e. permeability reached the minimum comparative values. Compressive strength is directly related to concrete density; concrete of high density exhibits high compressive strengths. Toner will enhance the compressive strength and permeability when added to the mix at 5\%, compared to the $1 \%$. This material can be used in the development of the FC to be used in the construction of light weight structural elements.

\section{REFERENCES}

[1] Nambiar E.K.K and Ramamurthy K., 2007b. Sorption characteristics of foam concrete, Cement and Concrete Research 37, pp. 1341-1347.

[2] Mydin, M.A.O. and Wang, Y.C. (2011). 'Structural performance of lightweight steel-foamed concrete-steel composite walling system under compression', Thin-Walled Structures, 49(1), pp. 66-76.

[3] British Cement Association, Ref. 46.042, 1994, pp 4. Foamed concrete; Composition and Properties.

[4] Dransfield J.M., 2000. Foamed Concrete: Introduction to the Product and its Properties, one-day awareness seminar on 'Foamed Concrete: Properties, Applications and Potential, University of Dundee, Scotland, pp. $1-11$.

[5] Jones, M.R. and McCarthy, A., 2005b. Preliminary views on the potential of foamed concrete as a structural material. Magazine of Concrete Research 57(1), pp. 21-31.

[6] Jones M.R., 2000. Foamed concrete for structural use, one-day awareness seminar on 'Foamed Concrete: Properties, Applications and Potential', University of Dundee, Scotland pp. 54-79.

[7] Amran, Y. H. M., Farzadnia, N. and Ali, A.A.A. (2015). 'Properties and applications of foamed concrete; a review', Construction and Building Materials, 101, pp. 990-1005.

[8] Panesar, D.K, (2013). 'Cellular concrete properties and the effect of synthetic and protein foaming agents', Construction and Building Materials, 44, pp. 575-584.

[9] Jones, M.R. and McCarthy, A., 2005c. Behaviour and assessment of foamed concrete for construction applications, Proceedings of the International Conference on the Use of Foamed Concrete in Construction pp. $61-88$.

[10] Nambiar E.K.K and Ramamurthy K., 2000. Structure and properties of aerated concrete: a review, Cement and Concrete Composites vol. 22 pp. $321-329$.

[11] Jones, M.R. and McCarthy, A., 2006. Heat of hydration in foamed concrete: Effect of mix constituents and Plastic density. Cement and Concrete Research 36(6), pp. 1032-1041.

[12] Jones M.R., McCarthy A and McCarthy M.J., 2003. Moving fly-ash utilisation in concrete forward: a UK perspective, Proceedings of the 'International Ash Utilization Symposium', Center for Applied Energy Research, University of Kentucky.

[13] McCarthy A., 2004. Thermally insulating foundations and ground slabs for sustainable housing using Foamed concrete, $\mathrm{PhD}$ Thesis, University of Dundee.

[14] Sandra V.P, 2014. Harvard Physico-chemical and toxicological studies of engineered nanoparticles emitted from printing equipment. Harvard school of public health.

[15] BS EN 12390-3:2009, Testing hardened concrete.

[16] BS EN 12390-8:2009, Testing for capillary water absorption.

[17] BS 1881-122:2011, Testing for total water absorption. 